\title{
Re: Huseynov et al.: The Effects of Previous Renal Stone Surgery on Percutaneous Nephrolithotomy Outcomes (Grand J Urol 2021;1:18-21)
}

\section{Re: Huseynov ve ark.: Geçirilmiş Böbrek Taşı Cerrahisinin Perkütan Nefrolitotomi Sonuçları Üzerine Etkileri (Grand J Urol 2021;1:18-21)}

Department of Urology, Abant Izzet Baysal University Faculty of Medicine, Bolu, Turkey

Cite as: Sogutdelen E, Kucukyangoz M. Re: Huseynov et al.: The effects of previous renal stone surgery on percutaneous nephrolithotomy outcomes (Grand J Urol 2021;1:18-21). Grand J Urol 2022;2(1):45-6.

Submission date: 21 April 2021

Acceptance date: 28 April 2021

Online First: 30 April 2021

Publication date: 20 January 2022

Corresponding Author: Emrullah Sogutdelen / Abant Izzet Baysal University Faculty of Medicine, Department of Urology, Bolu, Turkey / esdelen@gmail.com / ORCID ID: 0000-0002-1454-5672

\section{Dear Editor,}

I read the article by Huseynov et al., [1] in which they examined the effects of previous renal stone surgery on percutaneous nephrolithotomy outcomes with great interest. They concluded that previous renal stone surgery increases the risk of residual stone with a similar complication rate. However, I would like to highlight some issues regarding the methodology and the results of this study.

Using the method of percutaneous nephrolithotomy (PNL) in the treatment of renal stones $2 \mathrm{~cm}$ and greater is a gold standard according to European Association of Urology guidelines [2]. By increasing surgeon experience and technological development of tools using in PNL surgery increase the success of the surgery and decrease the complication rate. However, it is known that the success of PNL is also affected by some other influencers such as hydronephrosis, stone location, and as well as Hounsfield unit (HU) [3]. Gucuk et al. [4] showed that the higher HU values increase the stone-free rate and $\mathrm{HU}$ is an independent predictive factor affecting the success of PNL. In the study by Huseynov et al., the higher HU may influence the stone-free rate of patients in primary PNL. Therefore, we thought that it must be mentioned in the discussion.

Another issue that we have to be clear about is estimated blood loss and stone size. In addition to the decrease in hemoglobin level, the estimated blood loss during the surgery was analyzed but not mentioned how was calculated in the relevant section. Furthermore, calculation of stone size was also mentioned as it was multiplying two dimensions but in the result section, it was expressed the volume of stone in $\mathrm{mm}^{3}$ which means multiplying the three dimensions. For this reason, we are curious about your method of calculating the estimated blood loss during the operation and the technique of preoperative stone size calculation.

As a result, we think that other factors including stone location in the kidney affects the success PNL. Hence, it should be examined in the study, otherwise, mentioned in the limitations of this study.

Ethics Committee Approval: This article does not contain any studies with human participants performed by the author. Authorship Contributions: Any contribution was not made by any individual not listed as an author. Concept - E.S., M.K.; Design - E.S., M.K.; Supervision - E.S., M.K.; Resources - E.S., M.K.; Materials - E.S., M.K.; Data Collection and/or Processing - E.S., M.K.; Analysis and/or Interpretation - E.S., M.K.; Literature Search - E.S., M.K.; Writing - E.S., M.K.; Critical Review E.S., M.K.

Conflict of Interest: The author declares that he has no conflict of interest.

Financial Disclosure: No grants or funding was provided for this study. 


\section{References}

[1] Huseynov J, Kalfazde N, Guner E. The Effects of Previous Renal Stone Surgery on Percutaneous Nephrolithotomy Outcomes. Grand J Urol 2021;1(1):18-21. https://doi.org/10.5222/gju.2021.47966.

[2] Türk C, Neisius A, Petř́k A, Seitz C, Skolarikos A, Somani B, et al. EAU Guidelines on Urolithiasis. Eur Assoc Urol 2016;69:475-82.

https://uroweb.org/guideline/urolithiasis/.
[3] Jabrayilov H, Koparal M, Gürocak S, Küpeli B, Tan M. Factors Affecting the Success Rate of Percutaneous Nephrolithotomy in Paediatric Patients. J Clin Med 2018;7:43.

https://doi.org/10.3390/jcm7030043.

[4] Gücük A, Üyetürk U, Öztürk U, Kemahli E, Yildiz M, Metin A. Does the hounsfield unit value determined by computed tomography predict the outcome of percutaneous nephrolithotomy? J Endourol 2012;26:792-6.

https://doi.org/10.1089/end.2011.0518. 